\title{
Product Market Competition and Human Resource Practices in the Retail Food Sector
}

\author{
ELIZABETH DAVIS, MATTHEW FREEDMAN, \\ JULIA LANE, BRIAN MCCALL, NICOLE NESTORIAK, \\ and TIMOTHY PARK*
}

In the wake of Wal-Mart and other mass merchandisers' entry into food retailing, the nature of competition in the industry has changed radically. Using longitudinal data on workers and firms to construct measures of compensation and churning for traditional food retailers, this paper examines how these measures change in response to mass merchandiser entry. While there is considerable heterogeneity across retail food establishments, human resource practices are persistent even in the face of new external competition.

\section{Introduction}

Whereas Wal-Mart employees start at the same salary as unionized employees in similar lines of work, they make 25 percent less than their unionized counterparts

* The authors' affiliations are, respectively, Department of Applied Economics, University Of Minnesota, 1994 Buford Ave, St Paul, MN 55108-6040; ILR School, 359 Ives Hall East, Cornell University, Ithaca, NY 14853-3901; Suite 900, National Science Foundation, 4201 Wilson Blvd, Arlington, VA 22230; University of Michigan, 2108B School of Education Bldg., 610 East University Ave., Ann Arbor, MI 48109; Bureau of Labor Statistics, 2 Massachusetts Avenue, NE, Washington, DC 20212; 315C Conner, Agricultural and Applied Economics, University of Georgia, Athens, GA 30602-7509. E-mail: lane-julia@norc.uchicago.edu. The paper has benefited from helpful comments from Charlie Brown, Erica Groshen, James Hertel, Jean Kinsey, Anne Russell, Scott Scheuler, and two anonymous referees. This document reports the results of research and analysis undertaken by the U.S. Census Bureau staff. It has undergone a Census Bureau review more limited in scope than that given to official Census Bureau publications. This research is a part of the U.S. Census Bureau's Longitudinal Employer-Household Dynamics (LEHD) Program, which is partially supported by the National Science Foundation Grants SES-9978093 and SES-0427889 to Cornell University (Cornell Institute for Social and Economic Research), the National Institute on Aging Grant R01 AG018854-02, and the Alfred P. Sloan Foundation. The views expressed on statistical, methodological, and technical issues are those of the author(s) and not necessarily those of the U.S. Census Bureau, its program sponsors, or its data providers. Some of the data used in this paper are confidential data from the LEHD Program. The U.S. Census Bureau supports external researchers' use of these data through the Research Data Centers (http://www.ces.census.gov). For questions regarding the data, please contact Jeremy S. Wu, Program Manager, U.S. Census Bureau, LEHD Program, Attn: Holly Brown, Room 6H136C, 4600 Silver Hill Road, Suitland, Maryland 20746, USA (did.local.employment.dynamics@census.gov, http://lehd.did.census.gov).

Industrial Relations, Vol. 48, No. 2 (April 2009). (C) 2009 Regents of the University of California Published by Blackwell Publishing, Inc., 350 Main Street, Malden, MA 02148, USA, and 9600 Garsington Road, Oxford, OX4 2DQ, UK. 
after two years at the job. The rapid turnover-70 percent of employees leave within the first year - is attributed to a lack of recognition and inadequate pay, according to a survey Wal-Mart conducted. (PBS, February 2, 2004)

THERE IS ABUNDANT EVIDENCE THAT THE ENTRY OF WAL-MART AND "BIG BOX" STORES INTO RETAILING HAS FORCED RETAIL firms to rethink the way in which they do business - not only in terms of pricing, marketing, and distribution strategies, but also in terms of their human resource practices. Both anecdotal and case study evidence suggests that the proliferation of big-box stores has had a substantial impact on the labor market, raising a number of questions. How does an industry's labor market adjust in response to such competitive shocks? Confronted with large new competitors, do existing firms revamp the way in which they hire, promote, and compensate employees? Or do firms with older ways of doing business simply contract and exit, and get replaced by entering firms that adopt the new way of doing business? This paper combines the insights gained from case study work with a large-scale longitudinal employer-employee matched data set to examine the labor market adjustment of firms in response to competitive entry.

\section{Background}

The retail food industry has undergone significant changes in recent decades. Increased competition from alternative retail formats, such as warehouse clubs, mass merchandisers, and other supercenters, in combination with substantial technological change and declining unionization, has transformed the industry. Supermarkets have evolved from small, independently owned full-service establishments to large, administratively centralized, horizontally and sometimes even vertically integrated self-service chains.

Wal-Mart's encroachment into food retailing is a good example of the way in which supercenters have posed a significant challenge to traditional grocery firms. Close to 80 percent of supermarket managers identified the supercenter format used by Wal-Mart as the major threat to traditional grocery chains (National Grocers Association 2003). From a base of only ten supercenters in 1993, Wal-Mart has grown to over 2000 in 2008, and Wal-Mart's share of the grocery market, currently at 20 percent, continues to grow.

The retail food industry has also undergone substantial changes in business practices due to the emergence of new information technologies. Technological changes, including scanning technologies, computerized inventory-control methods, and systematic tracking of customers' buying habits, have eliminated 


\section{2 / Elizabeth Davis et al.}

the need for some manual tasks within stores while also "up-skilling" some positions by requiring a greater degree of computer literacy and technical knowledge (Walsh 1993). Sieling, Friedman, and Dumas (2001) comment on the wide range of new technologies and work processes designed to improve customer service that employees are expected to master. The introduction of continuous replenishment programs to control inventories, electronic data interchange, computer-assisted ordering, and standard bar codes have increased productivity. In addition, food retailers have experimented with an expanded range of specialized services that are more labor intensive and rely on the internal training and expertise of employees (Warner 2005).

Unions traditionally held substantial sway in the retail food industry. Partly due to union protection, supermarket jobs were among the most highly paid and highly coveted retail jobs only several decades ago (Hughes 1999). Since the 1980s, unions have become substantially less important as two-tier wage agreements have proliferated in the industry, generally resulting in new hires being paid much less than more tenured workers. Belman and Voos (2004) document a decline in the union wage differential in the retail food industry of 26 percentage points, attributing the change in part to the increasing dominance of Wal-Mart and other nonunion discounters.

Adjustments in Human Resource Practices by Food Retailers. The objective in this study is to examine the effect of changing product market competition on firm human resource practices, and in particular on the promotion, hiring, and wage setting practices of firms (Lazear and Oyer 2004). Studies of the impact of Wal-Mart suggest there is reason to expect a substantial effect. Hausman and Leibtag (2005) find a substantial drop in product prices as a result of Wal-Mart entry. Basker (2005) finds that the entry of Wal-Mart into an area has a positive short-run effect on retail industry employment at the county level that diminishes over time. Wholesale employment falls slightly in the aftermath of a Wal-Mart entry, which Basker (2005) attributes to Wal-Mart's vertical integration. Neumark, Zhang, and Ciccarella (2005), meanwhile, find that Wal-Mart stores reduce local retail employment, and they present some evidence that average payroll per worker also falls in the wake of Wal-Mart entry.

Case study evidence suggests that human resource strategies vary substantially across firms in the retail food industry, and that they have changed over time. Supermarkets historically provided a subset of retail jobs that were better paid than most and that provided some upward mobility. However, the predominant type of job in the supermarket industry has changed from a full-time, relatively well-paid position to a job with irregular 
and part-time hours, low pay, and few options for training and career advancement (Hughes 1999). In earlier work, we found that supermarkets with characteristics of internal labor markets (ILM) were not very likely to switch to non-ILM status due to competition from mass merchandisers (Davis et al. 2006). In this paper we extend that work by using new detailed measures of human resource practices and competition.

\section{Model}

In this section, we develop a simple model of skill acquisition and turnover to show what may happen to the labor market strategies of an existing firm when a new competitor enters the local product market. This is followed by its empirical counterpart.

Theoretical Model. For simplicity, we restrict attention to a two period time horizon and ignore discounting. Also, the model simplifies human resource strategies to a firm's choice to engage in firm-specific training. This is a costly activity that will increase the marginal revenue product of the worker within the firm, but only if the worker remains at the firm that provides the training. Clearly, human resource strategies entail much more than training, but this single dimension serves as an indicator of a more general set of policies by the firm.

Suppose that a worker's initial marginal revenue product in a firm is $x$. After one period, there is a firm-specific exogenous change in marginal revenue product of either $+\beta$ or $-\beta$, where the former occurs with probability $p$. Let the worker's outside alternative be $y$ per period. Finally, assume that a firm can train a worker at cost $c$ and that training increases a worker's marginal revenue product at the firm in the second period by $v .{ }^{1}$ In the absence of training, and assuming that $x \geq y$ but $x-\beta<y$, a worker will stay with the firm with probability $p$. Thus, in the absence of training, it will be optimal for a worker to work at a firm in period one if

$$
x+p(\beta+x)+(1-p) y>2 y \text { or }(1+p)(x-y)+p \beta>0 .
$$

\footnotetext{
${ }^{1}$ For simplicity, we assume that both training and individual productivity shocks are firm specific. Some examples of endogenous training models that allow for training spillovers across firms are Stevens (1994), Acemoglu and Pischke (1998), and Owan (2004).
} 


\section{4 / Elizabeth Davis et al.}

With training, a worker's second period marginal revenue product in the firm is either $x+v+\beta$ (with probability $p$ ) or $x+v-\beta$ (with probability $(1-p)$ ). In the former case, the worker will remain with the firm in period two, given the assumption earlier that $x+\beta>y$. In the latter case, the worker will leave the firm if $x+v-\beta<y$, or if

$$
(x-y)+(v-\beta)<0 .
$$

The value of training will depend on whether a worker chooses to stay in period two after receiving a negative marginal revenue product shock. This decision hinges on whether or not equation (1) is satisfied. If equation (1) is not satisfied, then the net value of training is

$$
[2 x+v-c+p \beta-(1-p) \beta]-[x+p(\beta+x)+(1-p) y],
$$

which reduces to

$$
(1-p)(x-y-\beta)+v-c .
$$

If equation (1) is satisfied, the net value of training is

$$
[x+p(\beta+x+v)+(1-p) y-\mathrm{c}]-[x+p(\beta+\mathrm{x})+(1-p) y],
$$

which simplifies to

$$
p v-c \text {. }
$$

Thus, depending on the costs and benefits of training, we have three possibilities: (a) a firm does not train workers and has a turnover rate of $(1-p)$, (b) a firm trains workers and has a turnover rate of $(1-p)$ (equation (1) is not satisfied), or (c) a firm trains workers and has a turnover rate of 0 (equation (1) is satisfied).

To model the impact of a new entrant, we must make assumptions about how that new entrant affects the parameters in the model. We assume that the value of workers' outside opportunities $(y)$ and the cost of training $(c)$ are unaffected by the new entrant, while sales and workers' marginal revenue products (i.e., the values of $x, v$, and $\beta$ ) are reduced in a proportionate fashion by a factor $\alpha$ by the new entrant. Thus, after entry we have $\alpha x, \alpha v$, and $\alpha \beta$, where $\alpha<1$. This would be a situation in which the costs of training and value of worker's next best alternative are unaffected by a new entrant, but in which the worker's nominal productivity at the firm is uniformly reduced by the factor $\alpha$ (perhaps because of a drop in the price of output due to increased competition).

It is clear that since $y$ is unaffected by entry, the firm's optimal strategy is to shut down for $\alpha$ sufficiently close to zero. The question that remains 
is whether firms that continue to operate in the post-entry regime change the amount of training they provide workers and whether turnover rates are altered. Equation (1) above becomes $\alpha(x+v-\beta)-y<0$ after entry. The value of training to a firm, conditional on no turnover, becomes $[\alpha(x-\beta)-y]$ $(1-p)+\alpha v-c$, while the value of training to a firm, conditional on a turnover rate of $(1-p)$, becomes $\alpha p v-c$.

Obviously, when $\alpha$ is sufficiently close to one, entry has no impact on the firm's training decisions and turnover rates. However, for lower values of $\alpha$, a firm whose pre-entry strategy consisted of training workers, which resulted in a turnover rate of zero, may continue to train workers post-entry yet see a rise in turnover rates to $p$. For other values of $\alpha$, the firm may discontinue training workers with a rise in turnover rates to $p$. Finally, as mentioned above, for values of $\alpha$ close to zero the firm may go out of business.

To summarize, the impact of entry on an incumbent firm may result in no change in the firm's human resource strategies (as proxied by training) but lead to an increase in turnover rates. Alternatively, a firm may eliminate training and also see a rise in turnover rates. In some circumstances, the firm may go out of business. An incumbent firm's response to entry depends on $\alpha$, which represents an index of competitive pressure exerted by the new entrant. Similar results would hold if the human resource strategy were to provide high average earnings, steep earnings trajectories, or greater within firm earnings dispersion.

Empirical Model. The theoretical model sketched above suggests that in the wake of the entry of a competitor, firms may change their human resource practices in an effort to adapt but may also be forced to exit. The first possibility would suggest the following specification:

$$
h r_{f g t}=\boldsymbol{x}_{f g t}^{\prime} \boldsymbol{\beta}+\boldsymbol{m} \boldsymbol{c}_{g t}^{\prime} \boldsymbol{\alpha}+\boldsymbol{m} \boldsymbol{m}_{g t}^{\prime} \boldsymbol{\delta}+\Psi_{f}+\varepsilon_{f g t} .
$$

The dependent variable in the regression, $h r_{f g t}$, reflects the human resource practices of firm $f$ in geographic area $g$ at time $t$; we describe the measures of human resource practices we use below. Meanwhile, $\boldsymbol{x}_{f g t}$ is a vector of time-varying observable firm characteristics measured at time $t, \boldsymbol{m} \boldsymbol{c}_{g t}$ is a vector of characteristics of the product market in geographic location $g$ at time $t$, and $\boldsymbol{m m}_{g t}$ is a vector of variables measuring the characteristics of mass merchandisers (including their entry) in the geographic location at time $t$. We also include a fixed effect, $\psi_{f}$, which captures firm heterogeneity in observed and unobserved characteristics that do not vary over time. Using these fixed effects, we effectively test for the effect of changes in the competitive structure of the local product market on changes in an establishment's HR 


\section{6 / Elizabeth Davis et AL.}

practices. ${ }^{2}$ Also, since unobserved characteristics of establishments are likely to be correlated within local markets, we correct standard errors by clustering on county.

The exit rate is modeled first in a logit specification,

$$
\log \left[\lambda_{f g t}^{E x i t} /\left(1-\lambda_{f g t}^{E x i t}\right)\right]=\boldsymbol{x}_{f g t}^{\prime} \boldsymbol{\beta}+\boldsymbol{m} \boldsymbol{c}_{g t}^{\prime} \boldsymbol{\alpha}+\boldsymbol{m} \boldsymbol{m}_{g t}^{\prime} \boldsymbol{\delta}+\boldsymbol{\gamma}_{t},
$$

and then using a discrete-time Meyer-type proportional hazard model,

$$
\log \left[-\log \left(1-\lambda_{f g t}^{E x i t}\right)\right]=\boldsymbol{x}_{f g t}^{\prime} \boldsymbol{\beta}+\boldsymbol{m} \boldsymbol{c}_{g t}^{\prime} \boldsymbol{\alpha}+\boldsymbol{m} \boldsymbol{m}_{g t}^{\prime} \boldsymbol{\delta}+\boldsymbol{\gamma}_{\boldsymbol{t}} .
$$

In each model, $\lambda_{f g t}^{E x i t}$ represents the discrete-time exit hazard rate for firm $f$ at time $t$ in geographic area $g$ and $\gamma_{t}$ is the time-varying baseline exit rate parameter. We estimate the discrete-time proportional hazard model in part as a check on the logit results, as the proportional hazard model reduces spurious duration dependence by controlling for the impact of observable establishment characteristics. The right-hand side variables in each of the models are defined as above, and again we allow for arbitrary correlation among observations within the same region by clustering standard errors from the regression on county.

The obvious econometric issue is that the decision of a mass merchandiser to enter the market is likely determined by the same set of potentially unobservable market characteristics that affect other retailers' human resource practices. ${ }^{3}$ If these characteristics do not change over time, the firm fixed effects in the human resources regressions mitigate this problem. In order to distinguish the impact of entry from the impact of market characteristics on firm behavior, we exploit the fact that while new entrants have freedom to choose a specific market to enter based on market characteristics,

\footnotetext{
${ }^{2}$ As a robustness check, we also experimented with a random effects model in which we assume that the intercept for a particular firm is a random variable that is uncorrelated with observable firm characteristics. The random effects model yielded similar results as the fixed effects model. To the extent that the data include nearly the universe of firms in the sample states and not a random draw of firms from a larger distribution, though, a fixed effects approach is more grounded in econometric theory and more intuitively appealing than a random effects approach. Additionally, random effects models are sensitive to assumptions on the statistical properties of the random variables, and in particular the independence of the random effects and the regressors. Failure of this assumption would mean that the random effects model would yield inconsistent parameter estimates.

${ }^{3}$ A good discussion of the identification issues is provided in Basker (2007). Despite the probable role of market characteristics in determining store location, Holmes (2005) argues that the particular geographic pattern of Wal-Mart store openings also suggests that costs associated with distribution of products, or "the economics of density," were key to Wal-Mart's location decisions. Wal-Mart's location strategy may have had more to do with its distribution network and may have been less influenced by market characteristics compared to the location decisions of other big retailers like Kmart and Target (Fedgazette 2006). Nonetheless, there are systematic differences between areas in which mass merchandisers tend to locate versus those in which they do not.
} 
the limited availability of vacant land means that the exact location of the store is not related to the human resource practices of its nearest neighbors. ${ }^{4}$ Recent empirical evidence (Fox, Montgomery, and Lodish 2004) also suggests that, while spending at grocery stores decreases with distance from home, spending at mass merchandisers does not. Moreover, Fox, Postrel, and McLaughlin (2007) find that the proximity of grocery stores does not affect a mass merchandiser's revenues but that the proximity of other mass merchandisers lowers revenues. This suggests that a mass merchandiser's decision of where to locate within a region is less sensitive to the locations of grocery stores than the location of other mass merchandisers within the region.

We therefore construct a measure of the distance of each grocery store to the nearest mass merchandiser. We also control for the number of mass merchandisers in the immediate area as well as overall county product and labor market conditions. We would expect that, all else equal, the greater the distance between each grocery store and the nearest mass merchandiser, the lower would be the direct competition in both the product and labor market.

Thus, our approach is analogous to a difference in differences approach. When measuring the impact of a mass merchandiser on a grocery store, the simple before and after comparison (a simple difference approach) is inappropriate due to the endogeneity of the location decision. We therefore compare the difference before and after entry to the counterfactual difference in which a mass merchandiser entered the area but did not locate closer to a grocery store than any preexisting mass merchandisers in the area. Hence, to implement our approach, we include not only the number of mass merchandisers in the vector $\boldsymbol{m m}_{g t}$, but also the minimum distance to the nearest mass merchandiser. It is the estimated coefficient of this latter variable that is used to measure the impact of mass merchandiser entry.

\section{Data and Measurement}

Constructing a data set that permits the analysis of the effects of changes in the product market on firm specific compensation policies requires information on firms, their workers, and the product markets in which they

\footnotetext{
${ }^{4}$ This is different from the approach used by Neumark et al. (2005) since the research question is broader than examining the impact of the entry of one particular firm.
} 


\section{8 / Elizabeth Davis et AL.}

operate. We rely on a new linked employer-employee database that also provides information on the location and industry of firms: the Longitudinal Employer-Household Dynamics (LEHD) Program at the U.S. Census Bureau (described in detail by Abowd et al. (2005) and Haltiwanger, Lane, and Spletzer (2006)). Briefly, the LEHD data consist of quarterly records of the employment and earnings of all workers who are covered by U.S. state unemployment insurance (UI) systems in the 1990s and early 2000s. ${ }^{5}$ About 96 percent of private wage and salary employment is covered by these systems, and each record includes a unique personal identifier as well as the unique identification number of each firm; this permits the construction of a quarterly longitudinal data set on employers and the employees who work for them. ${ }^{6}$ We match UI wage records with internal Census Bureau administrative data for eight states (California, Idaho, Illinois, Maryland, North Carolina, Oregon, Washington, and Wisconsin) to obtain key demographic information about workers at each of the firms in the sample, including date of birth, place of birth, sex, and educational attainment.

In order to obtain detailed address information about establishments in our sample, we use a Census Bureau data set containing unique commercial and residential addresses in a state, geographically coded to the Census Block and latitude/longitude coordinates. The quality of the geographic coding is discussed elsewhere (Freedman, Lane, and Roemer 2008). We use only establishments that are precisely geographically coded in the analyses presented, as using imprecisely coded establishments and assuming that they are either located at the centroids of their tracts/counties or distributed uniformly within their tracts/counties tended to result in spurious findings of heaping or dispersion, respectively. We also incorporate information from the BEA's local area annual estimates to obtain information on the product markets in which businesses in our sample operate. The data from the BEA include county-level measures of per capita income, county population, and county employment per square mile.

\footnotetext{
${ }^{5}$ As of February 2008, the program comprised 48 U.S. states. This is an ongoing project and additional states are expected to join the program. Because of the sensitivity of these data it is worth noting that the data are anonymized before they are used in any Census Bureau projects; all standard identifiers and names are stripped and replaced by a unique "protected identification key." Only Census Bureau employees or individuals who have Special Sworn Status are permitted to work with the data, and there are serious penalties for disclosing the identity of an individual or business. Any research must be for statistical purposes only, and must be reviewed by the Census Bureau and other data custodians. Under Title 13 of the U.S. code, any breach of confidentiality can result in prosecution in which violators are subject to a $\$ 250,000$ fine and/or 5 years in jail.

${ }^{6}$ Stevens (2002) describes coverage issues related to the LEHD database.
} 
Definitions and Measurement. The industry code that includes grocery stores is NAICS 44511 (supermarkets and other grocery (except convenience) stores), which, according to the Census Bureau, "comprises establishments generally known as supermarkets and grocery stores primarily engaged in retailing a general line of food, such as canned and frozen foods; fresh fruits and vegetables; and fresh and prepared meats, fish, and poultry. Included in this industry are delicatessen-type establishments primarily engaged in retailing a general line of food." Some small "mom-and-pop" stores fall into this category; this industry classification code is thus broader in scope than the group of stores of interest for this paper. Fortunately, the employment distribution of establishments is quite bimodal, which led us to subset the data to only include those establishments with at least fifteen full-quarter workers. A subsequent manual inspection of the names of the establishments included and excluded resulting from the application of the criterion confirmed the decision. The industry codes used to capture mass merchandisers were 452112 (discount department stores), and 4529 (other general merchandise stores), with the additional restriction imposed that full-quarter employment had to exceed 100 workers. While this industry is broader than the Wal-Mart supercenters highlighted earlier, much of the growth in the industry has been in supercenters where food is a major product line. ${ }^{7}$

Measures of Competitive Pressure. The rich geographic detail available in our data permits us to construct quite precise measures of product market competition for the retail food industry. In order to explain the construction of these measures, consider Figure 1.

Suppose $\mathrm{G}$ is the grocery establishment of interest. We draw a circle of 10 -mile radius around $\mathrm{G}$, presuming that this represents the relevant area in which $\mathrm{G}$ could potentially compete with mass merchandisers. Because the geographic coding of our data set is to the latitude and longitude of each establishment, we can calculate not only the number of mass merchandisers within this radius, but also the precise distance to each. Of particular interest is the distance to the closest mass merchandiser for reasons described above.

Measures of Human Resource Practices. The LEHD data provide universal information on both workers and firms, which permits the

\footnotetext{
${ }^{7}$ We experimented with changing the employment threshold for our mass merchandiser definition, and the results were largely unchanged. Due in part to disclosure issues, we cannot report these latter results.
} 
FIGURE 1

Measurement of Local Competition from Mass Merchandisers



construction of different measures of human resource practices at the establishment level. The measures of firm-level workforce characteristics we calculate are rarely captured on such a large scale. ${ }^{8}$ Although a wide variety of measures could be constructed, we follow the spirit of Lazear and Oyer (2004) in creating measures of the earnings distribution, turnover rates, and earnings growth. The measures of the earnings distribution at each establishment are the natural log of average quarterly earnings among all full-quarter workers in the establishment and the natural log of the standard deviation of quarterly earnings among all full-quarter workers in the establishment. The turnover measure is the churning rate of all full-quarter workers in the establishment, where the churning rate is defined to be

\footnotetext{
${ }^{8}$ Business identifiers on the LEHD data are State Employer Identification Numbers (SEINs), which are used for state government tax collection purposes. While SEINs are potentially more aggregated business entities than establishments, LEHD data provide for multi-unit SEINs breakouts of their establishments, which are termed SEIN units. Only for a subsample of multi-unit SEINs do we have information on precisely which individuals are employed at each SEIN unit, though we know total employment at each SEIN unit. Hence, for multi-unit SEINs, when the unit of work is unknown for a particular worker attached to an SEIN, LEHD imputes it based on the worker's place of residence and the distribution of employment across establishments within the SEIN. See Abowd et al. (2005) for details on the imputation procedure.
} 
accessions plus separations minus net employment change divided by employment (Burgess, Lane, and Stevens 2000). We also construct a measure of mean within-job wage growth for workers in each establishment. This measure constitutes the average across all full-quarter workers at the business of the difference between the log of the current-period annualized earnings and the log of prior-period annualized earnings. ${ }^{9}$

\section{Basic Facts}

We use the measures developed above to describe the basic trends in product market competition and human resource practices for firms in the retail food industry as well as their decision to exit.

Trends in Competition and Concentration. As in much of the retail industry, growth in employment and establishments in retail food has been driven largely by expansion among multi-unit firms. Rising competition from nontraditional food retailers, though, has presented new challenges to even the larger grocery chains.

As Figure 2 reveals, the average number of mass merchandisers close to a given grocery store has climbed in recent years. In addition, the mean distance between grocery store and mass merchandisers has decreased substantially; the average distance from a grocery store to the nearest mass merchandiser has dropped from over ten miles in 1992 to fewer than four miles in 2002. Other measures reinforce these findings. The share of grocery stores facing no immediate competition from mass merchandisers (i.e., there were no mass merchandisers within ten miles of the grocery establishment) has dropped from about one-fourth to under 10 percent over the past decade. Meanwhile, the share of grocery stores facing five or more mass merchandisers within ten miles has climbed from one in four to over half.

The dynamism of the market is evident from the entry and exit of grocery stores. Of the grocery establishments that existed in our sample at the start of 1997, just over a third were no longer there by the start of 2002, and of those that existed at the start of 2002, about half were not in existence in 1997. Much of the grocery store entry, like that of mass merchandisers, has been occurring in the largest, richest, most dense markets in recent years. That said, nearly 80 percent of the counties in the sample that witnessed the entry

\footnotetext{
${ }^{9}$ Measures of within-job wage growth are described in more detail in Brown, Haltiwanger, and Lane (2006).
} 
FIGURE 2

Average Number of Mass Merchandisers within Each Distance Band

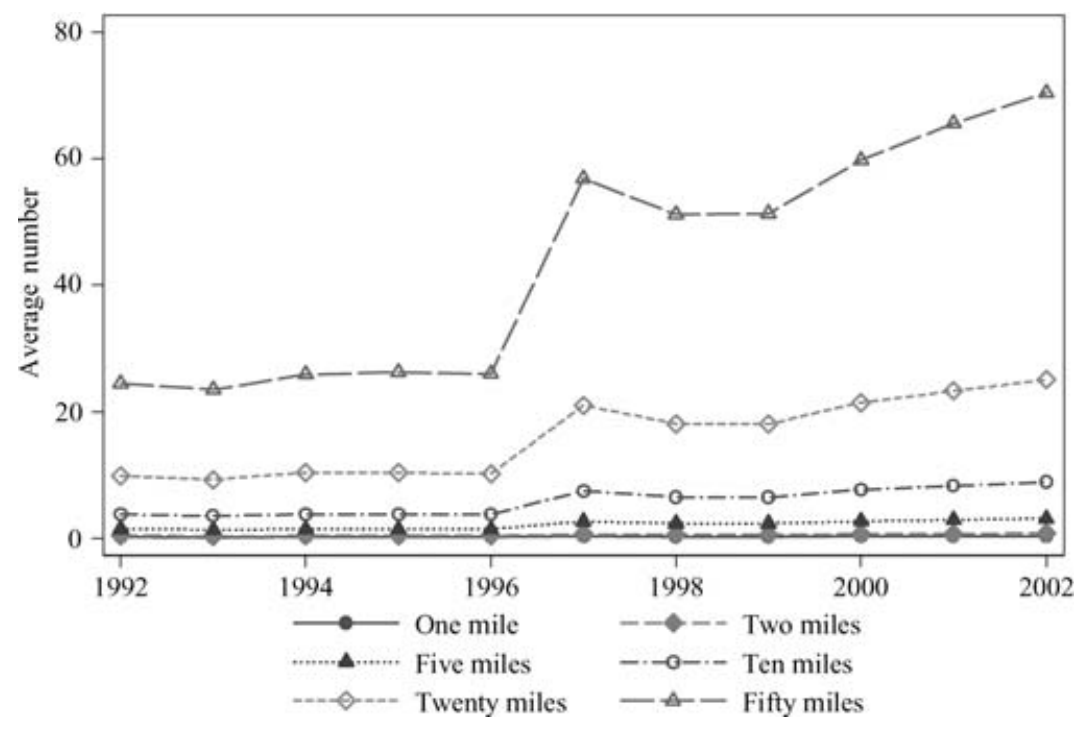

of a mass merchandiser between the start of 1997 and the start of 2002 saw either no change or a decline in the number of grocery establishments.

Competition and Human Resource Practices: Descriptive Statistics. Tables 1 and 2 provide basic statistics describing the differences in human resource practices and workforce composition between grocery stores and mass merchandise stores (MMs). Average earnings in mass merchandise stores are substantially lower than in grocery stores as a whole: about $\$ 2000$ less on a quarterly basis. ${ }^{10}$ Earnings dispersion is similarly more compressed for mass merchandise establishments than in grocery stores. Workforce instability is higher, however, as evidenced by higher churning rates. This is

\footnotetext{
${ }^{10}$ The earnings differential across industries that we observe LEHD data can also be found in surveybased data. In the 2002 American Community Survey (ACS), workers in general merchandise stores (NAICS 4529) report average annual wage and salary income of $\$ 13,083$. While the ACS does not break out discount department stores, workers in the broader department store industry (NAICS 45211) report average annual wage and salary income of $\$ 15,504$. Meanwhile, workers in grocery stores (NAICS 4451) in the same survey report average annual wage and salary income of $\$ 16,117$. The higher levels of earnings across industries that we find in the LEHD data may result from our focus on fullquarter workers, which eliminates very transient workers from the sample.
} 
TABLE 1

Basic Statistics, 2002Q1

\begin{tabular}{|c|c|c|c|c|c|}
\hline & \multirow[b]{2}{*}{$\begin{array}{l}\text { Mass merchandisers (MM) } \\
\text { All }\end{array}$} & \multicolumn{4}{|c|}{ Grocery stores } \\
\hline & & All & $\begin{array}{l}\text { No prior MM } \\
\text { competition }\end{array}$ & $\begin{array}{l}\text { Any prior MM } \\
\text { competition }\end{array}$ & $\begin{array}{c}\text { Always prior MM } \\
\text { competition }\end{array}$ \\
\hline Number & 999 & 1454 & 76 & 1378 & 1148 \\
\hline Full-quarter employment & 241.93 & 87.22 & 59.22 & 88.77 & 92.22 \\
\hline Mean quarterly earnings & $\$ 5442.20$ & $\$ 7672.56$ & $\$ 7576.96$ & $\$ 7677.83$ & $\$ 7693.34$ \\
\hline Standard deviation of earnings & $\$ 5003.92$ & $\$ 6074.70$ & $\$ 7039.11$ & $\$ 6021.51$ & $\$ 5684.20$ \\
\hline Mean within-job wage growth & $29 \%$ & $6 \%$ & $17 \%$ & $5 \%$ & $6 \%$ \\
\hline Accession rate & $13 \%$ & $7 \%$ & $7 \%$ & $7 \%$ & $6 \%$ \\
\hline Separation rate & $8 \%$ & $6 \%$ & $5 \%$ & $7 \%$ & $7 \%$ \\
\hline Job creation rate & $6 \%$ & $2 \%$ & $3 \%$ & $2 \%$ & $2 \%$ \\
\hline Job destruction rate & $1 \%$ & $2 \%$ & $1 \%$ & $2 \%$ & $2 \%$ \\
\hline Churning rate & $14 \%$ & $9 \%$ & $8 \%$ & $9 \%$ & $9 \%$ \\
\hline Change in employment & $5 \%$ & $0 \%$ & $2 \%$ & $0 \%$ & $0 \%$ \\
\hline Alive at least 1 year & $98 \%$ & $94 \%$ & $99 \%$ & $93 \%$ & $92 \%$ \\
\hline Alive at least 2 years & $86 \%$ & $88 \%$ & $95 \%$ & $88 \%$ & $86 \%$ \\
\hline Alive at least 4 years & $78 \%$ & $76 \%$ & $83 \%$ & $76 \%$ & $72 \%$ \\
\hline
\end{tabular}


TABLE 2

WORKFORCE STATISTICS, 2002Q1

\begin{tabular}{|c|c|c|c|c|c|}
\hline & \multirow[b]{2}{*}{$\begin{array}{c}\text { Mass merchandisers } \\
\text { All }\end{array}$} & \multicolumn{4}{|c|}{ Grocery stores } \\
\hline & & All & $\begin{array}{l}\text { No prior MM } \\
\text { competition }\end{array}$ & $\begin{array}{c}\text { Any prior MM } \\
\text { competition }\end{array}$ & $\begin{array}{c}\text { Always prior } \mathrm{MM} \\
\text { competition }\end{array}$ \\
\hline Number & 999 & 1454 & 76 & 1378 & 1148 \\
\hline \multicolumn{6}{|l|}{ Educational attainment } \\
\hline Share of workers less than HS degree & 0.51 & 0.44 & 0.45 & 0.44 & 0.44 \\
\hline Share of workers with HS degree & 0.31 & 0.32 & 0.32 & 0.32 & 0.32 \\
\hline Share of workers with college degree & 0.18 & 0.24 & 0.23 & 0.24 & 0.24 \\
\hline Total & 1.00 & 1.00 & 1.00 & 1.00 & 1.00 \\
\hline \multicolumn{6}{|l|}{ Foreign born status } \\
\hline Share of workers foreign born & 0.14 & 0.17 & 0.11 & 0.18 & 0.19 \\
\hline Share of workers not foreign born & 0.86 & 0.83 & 0.89 & 0.82 & 0.81 \\
\hline Total & 1.00 & 1.00 & 1.00 & 1.00 & 1.00 \\
\hline \multicolumn{6}{|l|}{ Gender and age } \\
\hline Share of workers male $<25$ & 0.11 & 0.12 & 0.11 & 0.12 & 0.12 \\
\hline Share of workers male $25-34$ & 0.12 & 0.13 & 0.12 & 0.13 & 0.13 \\
\hline Share of workers male $35-54$ & 0.13 & 0.21 & 0.18 & 0.21 & 0.22 \\
\hline Share of workers male $55+$ & 0.04 & 0.05 & 0.06 & 0.05 & 0.05 \\
\hline Share of workers female $<25$ & 0.11 & 0.10 & 0.11 & 0.10 & 0.10 \\
\hline Share of workers female $25-34$ & 0.14 & 0.12 & 0.12 & 0.12 & 0.12 \\
\hline Share of workers female $35-54$ & 0.25 & 0.23 & 0.26 & 0.23 & 0.23 \\
\hline Share of workers female $55+$ & 0.09 & 0.04 & 0.05 & 0.04 & 0.04 \\
\hline Total & 1.00 & 1.00 & 1.00 & 1.00 & 1.00 \\
\hline
\end{tabular}


not surprising given the lower average educational attainment levels among workers at mass merchandisers. As expected, mass merchandisers have substantially greater employment growth, and are significantly larger than grocery stores. Within-job wage growth is substantially higher in mass merchandiser stores than other stores, which probably reflects the "up or out" strategy that case study evidence has already identified.

Table 1 also provides information about the differences in human resource practices for grocery stores operating in product markets where mass merchandisers are present, versus those in which mass merchandisers are not present. Existing case study and empirical evidence suggests that mass merchandisers make their location decisions based at least in part on local demand conditions (Neumark et al. 2005; Drewianka and Johnson 2006), and Table 1 demonstrates that mass merchandisers are present in markets in which grocery stores pay higher average wages and in which earnings dispersion is greater.

Another way to examine the relationship between competition and human resource practices is to track changes in human resource practices in establishments as the degree of competition changes. In Figure 3, we plot each of the four measures of human resource practices in each establishment in 1997 against the same measure in 2002. Firms in markets that face a mounting competitive threat (an increase in the number of mass merchandisers within five miles of a given establishment) are denoted with a "+" while those facing a declining competitive threat (a decline in the number) with a " 0 ." The reference point 45 -degree line represents firms that did not change any practices at all over the period.

The results are quite striking. First, firms engage in very different human resource practices even within this very narrowly defined industry. Churning rates range from less than 10 percent to over 40 percent. The standard deviation of log earnings varies from seven points up to ten points. The indices of log mean earnings and workforce stability are similarly varied. Second, human resource practices are not adopted at random. Firms are heavily clustered around the 45-degree line regardless of which measure is used. The firms that had churning rates of 20 percent in 1997 have churning rates of about 20 percent 5 years later. Firms with a standard deviation of $\log$ earnings of ten points in 1997 have the similar standard deviation 5 years later. A third point is that these persistent and heterogeneous human resource strategies are, at best, only mildly responsive to changes in the external competitive environment. Across measures, there is no strongly evident difference among those grocery stores that face greater competition from mass merchandisers. However, these figures do not control for important differences among those grocery establishments that are more or less likely to witness entry; we address this in the next section. 
FIGURE 3

Human Resource Practices among Grocery Establishments Facing Increasing and DECREASING COMPETITION
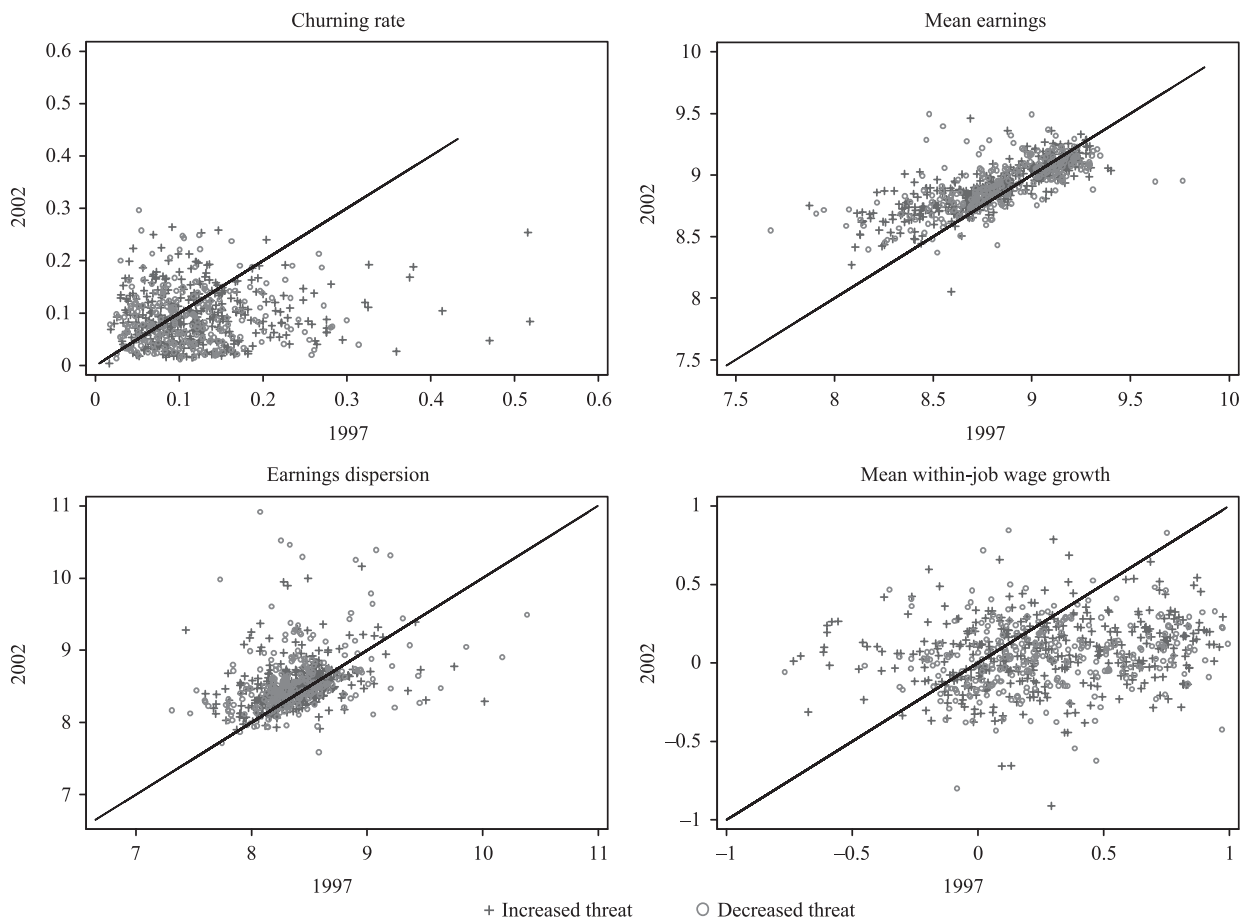

\section{Empirical Analysis}

We begin by estimating the equations outlined in the model above to examine the relationship between the four firm human resource practices measures and the geographic proximity to MMs. Time-varying establishment and product market characteristics are included to control for other factors that might affect the choice of human resource practices, such as size of the establishment (a quadratic in log employment), the demographic characteristics of the establishment's workforce (all variables included in Table 2), county per capita income, county population, and county employment density.

The results of estimating the first model appear in Table 3, with each of the four measures of human resource practices as dependent variables. Our findings are robust to a variety of different specifications and sets of control 
TABLE 3

Human Resource Practices and Competition

\begin{tabular}{lcccc}
\hline \hline & $\begin{array}{c}\text { Churning } \\
\text { rate }\end{array}$ & $\begin{array}{c}\text { Mean } \\
\text { earnings }\end{array}$ & $\begin{array}{c}\text { Standard } \\
\text { deviation of } \\
\text { earnings }\end{array}$ & $\begin{array}{c}\text { Within-job } \\
\text { wage growth }\end{array}$ \\
\hline Number of MM within 10 mile radius & 0.0008 & -0.0013 & -0.0034 & -0.0137 \\
Distance to nearest MM & $(0.0003)^{* *}$ & $(0.0012)$ & $(0.0021)^{*}$ & $(0.0051)^{* * *}$ \\
& -0.0001 & 0.0001 & 0.0003 & -0.0007 \\
Log FQ employment & $(0.0000)$ & $(0.0001)$ & $(0.0001)^{* *}$ & $(0.0002)^{* * *}$ \\
Log FQ employment squared & -0.0767 & 0.2747 & 0.3151 & 0.0232 \\
& $(0.0204)^{* * *}$ & $(0.0462)^{* * *}$ & $(0.1031)^{* * *}$ & $(0.0597)$ \\
Observations & 0.0052 & -0.0226 & -0.0132 & -0.0077 \\
Firms & $(0.0025)^{* *}$ & $(0.0058)^{* * *}$ & $(0.0136)$ & $(0.0075)$ \\
$R^{2}$ & 57,049 & 57,049 & 57,049 & 57,049 \\
\hline
\end{tabular}

NoтE: Fixed effect regressions with establishment fixed effects. Quarterly dummies included; also controls for demographic characteristics of workforce. Standard errors in parentheses allow for arbitrary correlation among observations within the same county. ${ }^{*}$ Significant at 10 percent, ${ }^{* *}$ significant at 5 percent, ${ }^{* * *}$ significant at 1 percent.

variables. ${ }^{11}$ As previously noted, the endogeneity of mass merchandiser entry is potentially problematic. However, inclusion of distance to the nearest mass merchandiser mitigates this issue.

There is very little clear pattern of change in human resource practices among grocery stores in response to increasing mass merchandiser competition. Not only are many of the coefficients on the competition variables in Table 3 statistically insignificant, but even those that are significant are small in magnitude. For example, using the first regression, the churning rate in establishments is 0.08 percentage points higher in an area with an additional mass merchandiser, and for every mile the nearest mass merchandiser is more closely located, the churning rate is 0.01 percentage points higher (and the latter effect is insignificant). Given that the average churning rate is around 10 percent and there is substantial variation around the average,

\footnotetext{
${ }^{11}$ In addition to a random effects approach that assumes that the intercept for a particular establishment is a random variable that is uncorrelated with observable establishment characteristics, we also experimented with a variety of specifications in order to test the sensitivity of our results to our measures of mass merchandiser competition (e.g., using 5-mile and 20-mile radii instead of a 10-mile radius), our product market controls, and our controls for establishment workforce composition. For the human resources regressions and the exit regressions, we also experimented with including interactions between our competition measures and establishment and local product market characteristics. These regressions produced qualitatively similar results.
} 


\section{8 / Elizabeth Davis eT AL.}

these magnitudes are small and are dwarfed by the effects of changes in other firm and local market characteristics. The effects of mass merchandiser entry on other measures of grocery stores' human resource practices are similarly small. Overall, the results suggest that retail food establishments are not making drastic changes in their human resource practices in response to the drastic changes occurring in the retail food product market.

The second possible response to increased competition is for establishments to exit the market. Again, because we have longitudinal data on establishments, we can directly estimate the probability of exit, controlling for the same set of factors as before. As previously noted, we estimate the model both in a logit specification and in a discrete-time Meyer-type proportional hazard specification. As before, although we only report a subset of the results with a full set of firm and local market controls and with standard errors clustered on county, our findings are robust to the inclusion or exclusion of a variety of the independent variables and different specifications.

The results of the exit regressions are reported in Table 4, and are also consistent with a priori expectations. The greater the number of mass merchandisers nearby, the higher the probability that a grocery establishment will exit. Similarly, the farther away the nearest mass merchandiser, the lower the probability that the establishment will exit.

The order of magnitude of the effect is also of interest. Using the regressions with or without interactions, for every additional mass merchandiser within ten miles of a grocery establishment, the odds of exit rise by nearly 4 percent according the logit model; the same calculation for the proportional hazard model suggests that the odds of exit rise by over 3 percent.

With regard to the distance to the nearest mass merchandiser, decreases in the distance increase the likelihood of exit. According to the models without interactions, a 1-mile decrease in the distance raises the odds of exit by between 1 percent and 2 percent.

The specifications that include interaction terms yield insight into the differential effects of mass merchandiser entry across different types of grocery establishments. In particular, the results indicate that, all else equal, smaller grocery stores appear to be less likely to exit than larger supermarkets as the distance to the closest mass merchandiser declines. Though the precision of the estimates is low, the results broadly suggest that larger supermarkets as opposed to smaller and perhaps specialized, niche grocers are more at risk of exiting due to the heightened competition resulting from the encroachment of mass merchandisers. In other words, the effects of competition may be attenuated the greater the extent to which a grocery establishment is an imperfect substitute for mass merchandisers in the retail food market. 
TABLE 4

Establishment Exit Probabilities

\begin{tabular}{|c|c|c|c|c|}
\hline & Logit model & $\begin{array}{c}\text { Logit model } \\
\text { with interactions }\end{array}$ & $\begin{array}{l}\text { Proportional } \\
\text { hazard model }\end{array}$ & $\begin{array}{c}\text { Proportional } \\
\text { hazard model } \\
\text { with interactions }\end{array}$ \\
\hline Number of MM within & 0.0372 & 0.0371 & 0.0333 & 0.0332 \\
\hline 10-mile radius & $(0.0126)^{* * *}$ & $(0.0125)^{* * *}$ & $(0.0100)^{* * *}$ & $(0.0099)^{* * *}$ \\
\hline Distance to nearest $\mathrm{MM}$ & $\begin{array}{l}-0.0191 \\
(0.0093)^{* *}\end{array}$ & $\begin{array}{c}-0.0070 \\
(0.0159)\end{array}$ & $\begin{array}{l}-0.0135 \\
(0.0079)^{*}\end{array}$ & $\begin{array}{c}-0.0026 \\
(0.0145)\end{array}$ \\
\hline Log FQ employment & $\begin{array}{l}-7.9270 \\
(0.5701)^{* * *}\end{array}$ & $\begin{array}{l}-7.9253 \\
(0.5883)^{* * *}\end{array}$ & $\begin{array}{l}-6.2026 \\
(0.5206)^{* * *}\end{array}$ & $\begin{array}{l}-6.1875 \\
(0.5247)^{* * *}\end{array}$ \\
\hline Log FQ employment squared & $\begin{array}{l}0.7254 \\
(0.0622)^{* * *}\end{array}$ & $\begin{array}{l}0.7275 \\
(0.0661)^{* * * *}\end{array}$ & $\begin{array}{l}0.5636 \\
(0.0557)^{* * *}\end{array}$ & $\begin{array}{l}0.5636 \\
(0.0570)^{* * *}\end{array}$ \\
\hline Distance * log FQ employment & & $\begin{array}{c}-0.0039 \\
(0.0038)\end{array}$ & & $\begin{array}{c}-0.0034 \\
(0.0036)\end{array}$ \\
\hline Observations & 55,503 & 55,503 & 55,503 & 55,503 \\
\hline
\end{tabular}

Our results are consistent with anecdotal evidence described by Warner (2005) and others: the entry of mass merchandisers increases the probability of exit among supermarkets overall, and particularly among relatively large supermarkets whose product and service offerings more likely overlap with those of mass merchandisers.

\section{Conclusions}

Despite rapid changes in the competitive landscape of food retailing in recent years, supermarkets and grocery stores do not appear to have made rapid adjustments in their human resource policies. While we find evidence of considerable heterogeneity in human resource practices across retail food establishments, these practices are quite persistent even in the face of new external competition. Technology, changing consumer preferences, and competition from nontraditional food retailers have led to major changes in supermarket operations, pricing, and supply chain strategies over the past decade. Yet, in terms of human resource practices, these firms seem slow to respond to external forces. Our analysis of employer-employee matched data supports the conclusions of case studies that find that, while human resources practices vary among food retailers, these practices are quite 


\section{0 / Elizabeth Davis et AL.}

persistent over time. Indeed, the margin of change in the industry appears to be through entry and exit.

\section{REFERENCES}

Abowd, John M., Fredrik Andersson, Kevin McKinney, Marc Roemer, Bryce Stephens, Lars Vilhuber, and Simon Woodcock. 2005. "The LEHD Infrastructure Files and the Creation of the Quarterly Workforce Indicators.” LEHD Technical User Guide, U.S. Census Bureau.

Acemoglu, Daron, and Jorn-Steffen Pischke. 1998. "Why do Firms Train? Theory and Evidence," Quarterly Journal of Economics 113:79-119.

Basker, Emek. 2005. "Job Creation or Destruction? Labor-Market Effects of Wal-Mart Expansion." Review of Economics and Statistics 87:174-83.

2007. "The Causes and Consequences of Wal-Mart's Growth." Journal of Economic Perspectives 21(3):177-98.

Belman, Dale, and Paula B. Voos. 2004. "Changes in Union Wage Effects by Industry: A Fresh Look at the Evidence." Industrial Relations 43:491-519.

Brown, Clair, John Haltiwanger, and Julia Lane. 2006. Economic Turbulence: The Impact on Workers, Firms and Economic Growth. Chicago, IL: University of Chicago Press.

Burgess, Simon, Julia Lane, and David Stevens. 2000. "Job Flows, Worker Flows and Churning." Journal of Labor Economics 18:473-502.

Davis, Elizabeth, Matthew Freedman, Julia Lane, Brian McCall, Nicole Nestoriak, and Timothy Park. 2006. "Supermarket Human Resource Practices and Competition from Mass Merchandisers." American Journal of Agricultural Economics 88(5):1289-95.

Drewianka, Scott, and Dain Johnson. 2006. "Wal-Mart and Local Labor Markets, 1990-2004.” University of Wisconson-Milwaukee Working Paper.

Fedgazette. 2006. "Thomas J. Holmes on Wal-Mart's Location Strategy." Federal Reserve Bank of Minneapolis 18:11-13.

Fox, Edward, Alan Montgomery, and Leonard Lodish. 2004. "Consumer Shopping and Spending Across Retail Formats." Journal of Business 77:S25-60.

, Steven Postrel, and Amanda McLaughlin. 2007. "The Impact of Retail Location on Retail Revenues: An Empirical Investigation.” Southern Methodist University, mimeo.

Freedman, Matthew, Julia Lane, and Marc Roemer. 2008. "New Approaches to Creating Data for Economic Geographers." Journal of Official Statistics 24:133-56.

Haltiwanger, John, Julia Lane, and Jim Spletzer. 2006. "Wage, Productivity and the Dynamic Interaction of Businesses and Workers." Labour Economics 14:575-602.

Hausman, Jerry, and Ephraim Leibtag. 2005. "Consumer Benefits from Increased Competition in Shopping Outlets: Measuring the Effect of Wal-Mart." Journal of Applied Econometrics 22:1157-77.

Holmes, Thomas J. 2005. "The Diffusion of Wal-Mart and the Economics of Density." University of Minnesota Working Paper.

Hughes, Katherine L. 1999. "Supermarket Employment: Good Jobs at Good Wages?” IEE Working Paper No. 11.

Lazear, Edward P., and Paul Oyer. 2004. "Internal and External Labor Markets: A Personnel Economics Approach.” Labour Economics 11:527-54.

National Grocers Association. 2003. Points of Impact, 2002-2003 Retail Operations Survey.

Neumark, David, Junfu Zhang, and Stephen Ciccarella. 2005. "The Effects of Wal-Mart on Local Labor Markets.” NBER Working Paper 11782.

Owan, Hideo. 2004. "Promotion, Turnover, Earnings and Firm-sponsored Training." Journal of Labor Economics 22:955-78.

Public Broadcasting System (PBS). 2004. "Store Wars: When Wal-Mart Comes to Town." http:// www.pbs.org/itvs/storewars/stores3.html. February 2, 2004.

Sieling, Mark, Brian Friedman, and Mark Dumas. 2001. "Labor Productivity in the Retail Trade Industry, 1987-99." Monthly Labor Review 124(12):3-14. 
Competition in Retail Food / 371

Stevens, David W. 2002. "Employment That Is Not Covered by State Unemployment." LEHD Technical Paper No. TP-2002-16.

Stevens, Margaret. 1994. "A Theoretical Model of On-the-job Training with Imperfect Competition." Oxford Economic Papers 46:537-62.

Walsh, John P. 1993. Supermarkets Transformed: Understanding Organizational and Technological Innovations. New Brunswick, NJ: Rutgers University Press.

Warner, Melanie. 2005. "An Identity Crisis for Supermarkets: Stores are Losing Shoppers to Specialty Chains and Discount Giants." New York Times, Health Section (October 6). 